\title{
Characterization and Taxonomic Classification of Soils in Onigambari Forest Reserve South Western Nigeria
}

\section{IHEDIUCHE, CI; OLAYIWOLA, VA; OJELABI, OK; ABIODUN, FO; OJEDOKUN, RO; AJIBOYE, OO; ISIENYI, NC}

Department of Soil and Tree Nutrition, Forestry Research Institute of Nigeria, PMB 5054, Jericho, Ibadan Oyo State, Nigeria

*Corresponding Author Email: iheduchecally@yahoo.com; Tel: +23408062274280

\begin{abstract}
A soil survey of Onigambari forest reserve in Oyo State, Nigeria was carried out. Three soil mapping units Established-Teak-Plantation (ETP), Natural-Forest (NF) and Farm-Land (FL) were identified with observation base on vegetative pattern. Morphological properties of the study area show that the soil unit ETP is deep and texture ranges from loamy-sand at the surface to sandy clay loam in the subsurface. The soil unit NF and FL is not deep due to presence of hard pan but the texture ranges from sandy-loam to sandy-clay and loamysand to sandy-clay respectively. Physical properties of the soils showed the bulk density of the soils to be moderately good for growing plant with high porosity. The soils chemical properties indicate that the $\mathrm{pH}$ value of the soils in ETP, NF and FL are slightly acidic and organic-matter was very low in the soils of ETP compared to NF and FL soils. The total-nitrogen values of the soils in the area changed irregularly with depth and values ranged from 0.028 to $0.1 \mathrm{~g} \mathrm{~kg}^{-}$in ETP, 0.05 to $0.25 \mathrm{~g} \mathrm{~kg}^{-1}$ in NF, the value ranged from 0.03 to $0.26 \mathrm{~g} \mathrm{~kg}^{-1}$ in FL. 0.03 to $0.26 \mathrm{~g} \mathrm{~kg}^{-1}$. According to USDA soil Taxonomy system, all the profiles pits in the study area showed distinguishing characteristics of the order Alfisols, therefore the soils are classified as Alfisols. Profile in the Established-Teak-Plantation is classified as Typic isohyperthermic paleustalfs, Profiles Natural-Forest and FarmLand with petro-plinthic material within $100 \mathrm{~cm}$ of the soil surface qualified as plinthic isohyperthermic paleustalfs.
\end{abstract}

\section{DOI: https://dx.doi.org/10.4314/jasem.v25i12.7}

Copyright: Copyright (C) 2021 Ihediuche et al. This is an open access article distributed under the Creative Commons Attribution License (CCL), which permits unrestricted use, distribution, and reproduction in any medium, provided the original work is properly cited.

Dates: Received: 22 August 2021; Revised: 17 September 2021; Accepted: 06 October 2021

Keywords: Taxonomy, classification, forest Reserve, characterization and soil survey

The coupling of soil characterization and soil classification provides a powerful resource for the benefit of mankind especially in the area of food security and environmental sustainability. Soil characterization provides the information for our understanding of the physical, chemical, mineralogical and microbiological properties of the soils we depend on to grow crops, sustain forests and grasslands as well as support homes and society structures (Ogunkunle, 2005). Soil classification, on the other hand, helps to organize our knowledge, facilitates the transfer of experience and technology from one place to another and helps to compare soil properties. According to (Eswaram 1977), some different uses of soil characterization data include to aid in the correct classification of the soil and enable other scientists place the soils in their taxonomies or classification systems and to serve as a basis for more detailed evaluation of the soil as well as gather preliminary information on nutrient, physical or other limitations needed to produce a capability class. A soil characterization study, therefore, is a major building block for understanding the soil, classifying it and getting the best understanding of the environment (Esu 2005). Owing to the fact that Onigambari is outskirt of Ibadan city and not much study has been done on the soils of the area, characterization and taxonomic classification will help reveal information that could be useful in the management and use of the soils for sustainability hence the need to characterize and classify the soils of Onigambari forest reserve.

\section{MATERIALS AND METHOD}

Study area: The study area is located within rain forest of South western Nigeria. The geographical location falls within latitude $7^{\circ} 23^{\prime} \mathrm{N}$ and longitude $3^{\circ} 33^{\prime} \mathrm{E}$, and covers an area of 11,618 hectares, between the river Ona on the west and on the eastern part of the main road from Ibadan to Ijebu-Ode. The average altitude of the Reserve falls between $122 \mathrm{~m}$ to $152 \mathrm{~m}$ (asl.) and its topography is more or less undulating. It has an annual rainfall of $1592.3 \mathrm{~mm}$ with a relative humidity of $78-84.5 \%$ and a mean temperature of $26.4^{\circ} \mathrm{C}$ (FRIN, 2013). 
Field study: Guided by the base map of the study area, a free method of soil survey was used on the field for the identification of the soil units with observations based on vegetation pattern.Three modal profile pits were dug and studied in each identified soil mapping unit under established teak plantation, natural forest and farm land. The soil profiles were described according to FAO (2006) manual while samples were collected from each horizon of the profile pits for laboratory analysis. Likewise, with the aid of core samplers, samples were taken from the various horizons for the determination of bulk density as described by Blake and Hartge (1986)

Table 1: Morphological Properties of the Soils at Onigambari Forest Reserve

\begin{tabular}{|c|c|c|c|c|c|c|c|}
\hline Pedon & Horizon & Depth(cm) & Boundary & Colour moist & Structure & Consistence & Root \\
\hline & & ETP & & & & & \\
\hline \multirow[t]{7}{*}{1} & $\mathrm{AP}$ & $0-12$ & No mottle & $5 \mathrm{YR} 4 / 2$ & 2Fsbk & Lo & $3 \mathrm{fr}$ \\
\hline & $\mathrm{AB}$ & $12-20$ & Few mottle & $5 Y R 4 / 4$ & 2Fbsk & Sfr & $3 \mathrm{fr}$ \\
\hline & BA & $20-30$ & More mottle & $2.5 \mathrm{YR} 4 / 6$ & $3 \mathrm{fsbk}$ & Vfr & $2 \mathrm{mp}$ \\
\hline & B1 & $30-50$ & Very few & $2.5 \mathrm{YR} 5 / 4$ & $3 \mathrm{fsbk}$ & Vfr & $1 \mathrm{fp}$ \\
\hline & B2 & $50-80$ & None & 5YR7/6 & $2 \mathrm{csbk}$ & $\mathrm{nf}$ & $\mathrm{nr}$ \\
\hline & $\mathrm{BC}$ & $80-150$ & None & $5 \mathrm{YR} 8 / 2$ & $3 \mathrm{csbk}$ & $\mathrm{Nf}$ & $\mathrm{nr}$ \\
\hline & & $\mathrm{NF}$ & & & & & \\
\hline \multirow[t]{5}{*}{2} & A & $0-15$ & No mottle & 5YR3/4 & $2 \mathrm{csbk}$ & Fr & $3 \mathrm{fr}$ \\
\hline & $\mathrm{AB}$ & $15-30$ & Very few mottle & $5 \mathrm{YR} 5 / 3$ & $2 \mathrm{fsbk}$ & Lo & $3 \mathrm{fr}$ \\
\hline & B & $30-50$ & No mottle & $2.5 \mathrm{YR} 5 / 6$ & $2 s g$ & Fr & $1 \mathrm{fp}$ \\
\hline & $\mathrm{BC}$ & $50-90$ & No mottle & $2.5 \mathrm{YR} 5 / 4$ & $1 \mathrm{csbk}$ & Lo & $\mathrm{nr}$ \\
\hline & & FL & & & & & \\
\hline \multirow[t]{4}{*}{3} & AP & $0-10$ & None & 5YR3/1 & $2 \mathrm{fsbk}$ & Vfr & $3 \mathrm{fr}$ \\
\hline & $\mathrm{AB}$ & $10-25$ & None & 5YR5/3 & $2 \mathrm{fsbk}$ & $\mathrm{Fr}$ & $3 \mathrm{fr}$ \\
\hline & B & $25-45$ & None & $5 Y R 4 / 4$ & $2 s g$ & Lo & $1 \mathrm{fr}$ \\
\hline & $\mathrm{BC}$ & $45-80$ & More mottle & 5YR5/6 & $1 \mathrm{csbk}$ & Lo & $\mathrm{Nr}$ \\
\hline
\end{tabular}

Determined at wet condition, Note: symbols or codes according to FAO, 2006; NOTE: ETP= Establish Teak Plantation, NF = Natural Forest and $F L=$ Farm Land; Structure: $0=$ structureless, $1=$ weak, $2=$ moderate, $3=$ strong, sg=single grain, csbk = coarse subangular blocky, fsbk= fine, subangular blocky, $m=$ massive; Consistence: lo=loose, sfr = slightly friable, vfr=very friable; Nf $=$ not friable; Roots:

$1=$ few $2=$ moderate, $3=$ many, fr= fine roots, co=coarse, $m p=$ many pores, $f p=f e w$ pores, nr: no root. Boundary: $A=$ abrupt, $C=c l e a r$, $G=$ gradual, $S=$ smooth, $W=$ wavy

Laboratory methods: The samples were air-dried, gently crushed using a wooden mortar and pestle and then sieved through a $2 \mathrm{~mm}$ mesh. The sieved samples were stored for chemical and physical analyses. Particle size distribution was determined by the hydrometer method (Gee and Or., 2002) Soil pH (1:1) in $\mathrm{H} 20$ and $\mathrm{CaCl} 2$ were determined using glass electrode $\mathrm{pH}$ meter (Thomas, 1996). Organic carbon content of the soils was determined by the modified Walkley-Black method as described by Nelson and Somners (1996). Total nitrogen was determined by the Macro-Kjeldahl digestion and distillation procedures as described by Bremner (1996). Available P was determined by (Kuo, 1996). Exchangeable bases (calcium, magnesium, potassium and sodium) in the soil were determined using the ammonium acetate extract from the CEC determination (Thomas, 1982). Sodium and $\mathrm{K}$ was determined using flame photometer and $\mathrm{Ca}$ and $\mathrm{Mg}$ were determined using atomic absorption spectrometer. Particle density was determined by the use of Pycnometer bottle method (Blake, 1965). Total porosity was calculated from particle and bulk densities using the relationship
$\mathrm{P}=100(1-\mathrm{Bd} / \mathrm{Pd})$, where $\mathrm{P}=$ porosity, $\mathrm{Bd}=$ Bulk density, $\mathrm{Pd}=$ Particle density and 100 and 1 are constants.

\section{RESULT AND DISCUSSION}

Morphological Characteristics: The morphological properties of the soils presented in Table 1 shows that the soil in established teak plantation unit (ETP) were dark brown (5YR4/2) at the surface and changes to brown (2.5YR4/6) at subsurface and reddish yellow (5YR7/6) down the horizons. The structure of the soils were moderately fine subangular blocky and changes to coarse subangular blocky in the subsurface. In soil unit of natural forest (NF) the surface colour of the soils was dark reddish brown (5YR3/4), changing to brown (2.5YR5/4) at subsurface. The structure of the soils were moderately coarse subangular blocky and changes to weak coarse subangular blocky in the subsurface. The soils in farm land (FL) were very dark brown (5YR3/4) at the surface and changed to reddish brown (5YR5/6) at subsurface, the structure were mostly subangular blocky 
Table 2: Some Selected Physical Characteristic of the Soils at Onigambari Forest Reserve

\begin{tabular}{lllllllll}
\hline Pedon & $\begin{array}{l}\text { Depth } \\
(\mathbf{C m})\end{array}$ & $\begin{array}{l}\text { Sand } \\
(\boldsymbol{\%})\end{array}$ & $\begin{array}{l}\text { Clay } \\
(\boldsymbol{\%})\end{array}$ & $\begin{array}{l}\text { Silt } \\
(\boldsymbol{\%})\end{array}$ & Textural class & $\begin{array}{l}\text { Bulk density } \\
(\mathbf{k g} / \mathbf{m})^{3}\end{array}$ & $\begin{array}{l}\text { Total } \\
\text { porosity }(\boldsymbol{\%})\end{array}$ & $\begin{array}{l}\text { Saturated } \\
\text { Conductivity }(\mathrm{cm} / \mathrm{sec})\end{array}$ \\
\hline 1 ETP & $0-12$ & 80.5 & 7 & 12.5 & Loamy sand & 1.20 & 54.54 & 0.003273 \\
& $12-20$ & 82.5 & 11 & 6.5 & Loamy sand & 1.35 & 48.92 & 0.002946 \\
& $20-30$ & 80.5 & 17 & 2.5 & Sandy loam & 1.41 & 46.72 & 0.006244 \\
& $30-50$ & 68.5 & 27 & 4.5 & Sandy clay loam & 1.38 & 47.94 & 0.008729 \\
& $50-80$ & 62.5 & 33 & 4.5 & Sandy clay loam & 1.15 & 56.74 & 0.003071 \\
& $80-150$ & 66.5 & 27 & 6.5 & Sandy clay loam & 1.07 & 59.65 & 0.006911 \\
$\mathbf{2}$ NF & $0-15$ & 76.5 & 15 & 8.5 & Sandy loam & 1.08 & 59.25 & 0.016004 \\
& $15-30$ & 80.5 & 13 & 6.5 & Sandy loam & 1.41 & 46.96 & 0.005214 \\
& $30-50$ & 54.5 & 39 & 6.5 & Sandy clay & 1.24 & 53.11 & 0.007275 \\
$\mathbf{3}$ FL & $50-90$ & 50.5 & 47 & 2.5 & Sandy clay & 1.31 & 50.42 & 0.009578 \\
& $0-10$ & 80.5 & 7 & 12.5 & Loamy sand & 1.17 & 55.76 & 0.005783 \\
& $10-25$ & 86.5 & 7 & 6.5 & Loamy sand & 1.41 & 46.72 & 0.004291 \\
& $25-45$ & 82.5 & 11 & 6.5 & Loamy sand & 1.34 & 49.27 & 0.013202 \\
& $45-80$ & 72.5 & 21 & 6.5 & Sandy clay loam & 1.34 & 49.41 & 0.013174 \\
\hline
\end{tabular}

\begin{tabular}{|c|c|c|c|c|c|c|c|c|c|c|c|c|c|c|c|}
\hline Pedon & Horizon & $\begin{array}{l}\text { Depth } \\
(\mathbf{C m})\end{array}$ & $\begin{array}{l}\mathrm{Ph} \\
\mathrm{H} 2 \mathrm{O})\end{array}$ & $\begin{array}{l}\text { Org. } \\
\text { Carbon } \\
(\%)\end{array}$ & $\begin{array}{l}\text { Org. } \\
\text { Matter } \\
(\%)\end{array}$ & $\begin{array}{l}\text { Total } \\
\text { Nitrogen }\end{array}$ & $\begin{array}{l}\mathrm{Na} \\
\mathrm{cmol} / \mathrm{kg}\end{array}$ & $\begin{array}{l}\mathrm{Ca} \\
\mathrm{cmol} / \mathrm{kg}\end{array}$ & $\begin{array}{l}\mathrm{Mg} \\
\mathrm{cmol} / \mathrm{kg}\end{array}$ & $\begin{array}{l}\mathrm{K} \\
\mathrm{cmol} / \mathrm{kg}\end{array}$ & $\begin{array}{l}\mathrm{P} \\
\mathrm{mg} / \mathrm{kg}\end{array}$ & $\begin{array}{l}\mathrm{Fe} \\
\mathrm{mg} / \mathrm{kg}\end{array}$ & $\begin{array}{l}\mathrm{Cu} \\
(\mathrm{mg} / \mathrm{kg})\end{array}$ & $\begin{array}{l}\mathrm{Mn} \\
\mathrm{mg} / \mathrm{kg}\end{array}$ & $\begin{array}{l}\mathrm{Zn} \\
\mathrm{mg} / \mathrm{kg}\end{array}$ \\
\hline \multirow[t]{6}{*}{1 ETP } & AP & $0-12$ & 6.29 & 1.2 & 2.06 & 0.1 & 0.617 & 6.986 & 1.217 & 0.084 & 1.947 & 18 & 5 & 184 & 9 \\
\hline & $\mathrm{AB}$ & $12-20$ & 6.89 & 0.08 & 1.89 & 0.09 & 0.626 & 5.19 & 1.053 & 0.084 & 1.790 & 24 & 4.3 & 82 & 6.5 \\
\hline & BA & $20-30$ & 5.48 & 0.62 & 1.07 & 0.053 & 0.635 & 3.393 & 1.743 & 0.115 & 1.867 & 31 & 3.5 & 70 & 5.1 \\
\hline & B1 & $30-50$ & 6.81 & 0.74 & 1.27 & 0.064 & 0.539 & 7.585 & 2.533 & 0.084 & 1.738 & 31 & 4.9 & 36 & 4.6 \\
\hline & B2 & $50-80$ & 6.91 & 0.8 & 1.36 & 0.069 & 0.696 & 9.381 & 2.5 & 0.1 & 1.806 & 31 & 3.4 & 15 & 4.5 \\
\hline & $\mathrm{BC}$ & $80-150$ & 6.21 & 0.32 & 0.55 & 0.028 & 0.591 & 8.184 & 3.947 & 0.1 & 1.947 & 30 & 3.3 & 14 & 5.1 \\
\hline \multirow[t]{4}{*}{$2 \mathrm{NF}$} & A & $0-15$ & 6.27 & 2.91 & 5.02 & 0.25 & 0.913 & 10.978 & 2.829 & 0.261 & 2.076 & 19 & 3.9 & 100 & 9.7 \\
\hline & $\mathrm{AB}$ & $15-30$ & 6.77 & 0.66 & 1.13 & 0.059 & 0.626 & 4.192 & 2.368 & 0.092 & 2.041 & 24 & 4.4 & 25 & 6 \\
\hline & B & $30-50$ & 6.58 & 1.02 & 1.75 & 0.088 & 0.652 & 3.792 & 3.586 & 0.177 & 1.992 & 31 & 2.3 & 26 & 4.8 \\
\hline & $\mathrm{BC}$ & $50-90$ & 6.35 & 2.65 & 4.57 & 0.23 & 0.652 & 4.591 & 2.895 & 0.169 & 1.961 & 26 & 3.2 & 19 & 5.1 \\
\hline \multirow[t]{4}{*}{3 FL } & $\mathrm{AP}$ & $0-10$ & 6.18 & 1.2 & 2.06 & 0.1 & 0.739 & 8.982 & 1.382 & 0.115 & 1.954 & 17 & 2 & 118 & 9.5 \\
\hline & $\mathrm{AB}$ & $10-25$ & 5.27 & 0.8 & 1.36 & 0.069 & 0.574 & 3.194 & 2.105 & 0.054 & 1.959 & 25 & 3.5 & 17 & 4.1 \\
\hline & B & $25-45$ & 6.92 & 0.38 & 0.65 & 0.033 & 0.609 & 2.994 & 2.303 & 0.054 & 2.025 & 29 & 3.2 & 5 & 4.7 \\
\hline & BC & $45-80$ & 6.05 & 3.03 & 5.28 & 0.26 & 0.635 & 5.19 & 2.072 & 0.092 & 2.010 & 28 & 4.7 & 20 & 7.5 \\
\hline
\end{tabular}

Physical Characteristics: Generally, it was observed that the soils of the study area have high sand content at surface and decrease down the depth in all profile. The silt content of the soils was observed to be high at the surface and decreases with increasing depth in all the profiles. The clay content of the soils was also observed to increase as the depth increases in all the profiles. The textural class ranges from loamy sand to sandy clay loam in
ETP soil while in NF soil; it ranges from sandy loam to sandy clay but from loamy sand to sandy clay in FL soil. The bulk density of the soils collected from ETP, NF and FL all ranges from fine texture soil to medium texture soil in table 2 
Chemical Characteristics: The $\mathrm{pH}$ value of the soil in ETP, NF and FL shows that the soils of this study area are slightly acidic (table 3) in Onigambari forest reserve. Organic matter was very low in the soils of ETP compared to NF and FL soils according to Landon (1991) ratings ( $>20 \%$ very high, 10-20\% high, 4-10\% medium, 2-4 \% low and $<2 \%$ very low). Total Nitrogen values ranged from 0.028 to $0.1 \mathrm{~g} \mathrm{~kg}^{-1}$ in ETP, 0.05 to $0.25 \mathrm{~g} \mathrm{~kg}^{-1}$ in NF, the value ranged from 0.03 to $0.26 \mathrm{~g} \mathrm{~kg}^{-1}$ in FL. The total nitrogen values of the soils in the area changed irregularly with depth. The concentrations of $\mathrm{Na}^{+}$and $\mathrm{Ca}^{2+}$ all ranges from low to high, those of $\mathrm{Mg}^{2+}$ ranged from low to medium while those of $\mathrm{K}^{+}$, ranged from very low to low (Agbede, 2009) as shown on Table.3 However, the micro-nutrients; $\mathrm{Fe}^{2+}, \mathrm{Cu}^{2+}$ and $\mathrm{Zn}^{2+}$ were in present the soils irrespective of the pedon nor soil horizon in very low values while $\mathrm{Mn}^{2+}$ concentrations in the soils were medium ranged.(Alloway,2004andLee,2008).

Conclusions: The soils of the studied area (Rainforest) were derived from fine grained granite gneisses, which are the parent rock of soils of Egbeda Association (Smyth and Montgomery, 1962). Profile within the Natural Forest is classified as Balogun series, Profile within the Farm land is classified as Egbeda series and Profile within the established teak plantation is classified as Oba series. All the profiles studied from the study area showed differentiating characteristics of the order Alfisols, hence the soils are classified as Alftisols. The soil moisture regime of the studied area is classified as Ustic, therefore the soils are in ustalfs suborder. Soil temperature regime in southwestern Nigeria is isohyperthermic with ochric epipedon. Profile in the established teak plantation is therefore classified as Typic isohyperthermic paleustalfs Profiles NF and FL with petro-plinthic material within $100 \mathrm{~cm}$ of the soil surface qualified as plinthic isohyperthermic paleustalfs

\section{REFERENCE}

Agbede O.O. (2009). Understanding Soil and Plant Nutrition Book. ISBN: 978-978-900-087-6, First edition. pp. 197.

Alloway, B.J. (2004)., Zinc in soils and crop nutrition, pp1-116, International Zinc Association, Brussels.

Blake G.R., and Hartge, K.H. (1986). Bulk density. In methods of Soil Analysis. Klute A. (Ed). Part 1. 2nded. Agron. 9. ASA and SSA, Madison, W1. P.363375

Bremner JM. Nitrogen-total Nitrogen-total Madison, WI, USA 1996; 1085-121.
Esu, I.E (2005). Soil characterization and mapping forfood security. A Keynote Address at the

$29^{\text {th }}$ annual conf. of SSSN held at University of Nigeria, Abeokuta, from 6th to 10th Dec. 2004

Eswaran, H. (1977). Soil Analysis for Soil Surveys. In:Soil Resource Inventories. A proceedings of a workshop held at Cornell University, Ithaca, USA,pp 315-324

FAO Food and Agriculture Organization). Guidelines for Field Soil Descriptions (4th edition) Publishing Management Service Information Division, FAO, Rome (2006)

FRIN (2013). Forestry research institute of Nigeria. Annual Meteorological report

Gee GW, Or D. Particle-size analysis.Methods of soil analysis, Part 4 Physical methods Book Series No 5 2002; 255-93.

Kuo, S (1996) Phosphorus. In Sparks, D.L., Ed., Methods of soil Analysis part 3, Chemical Methods, SSSA Book Series 5, soil science society of America, Madison, Wisconsin, 869-920.

Landon JR (1991). Tropical Soil Manual: A Handbook for Soil Survey and Agricultural Land Evaluation in Tropics and Subtropics

Lee Jacobs, 2008, Micronutrients needed by crops, department of crop and soil sciences Michigan State University

Ogunkunle A.O.; (2005). Soil Survey and SustainableLand Management. Invited paper at the $29^{\text {th }}$ annual conf. of SSSN held at University of Nigeria,Abeokuta, from 6th to 10th Dec. 2004.

Nelson DW, Sommers LE. Total carbon, organic carbon and organic matter. In: Sparks, D.L, (ed.). Methods of soil analysis. Part 3. 2nd ed. SSSA Book Series No. 5. Madison (WI): ASA and SSSA. 1996; p. 9611010

Thomas, GW (1996) Soil pH and Soil Acidity. In sparks, DL, Ed., Methods of soil Analysis part 3 chemical methods, SSSA Book series 5, soil science society of America, Madison, Wisconsin, 475-490

Thomas, GW (1982) Exchangeable Cations. Methods of soil Analysis part 2, Chemical and microbiological properties, Second Edition A.L. page (editor). Agronomy, No 9, part2, American society of Agronomy, soil science society of America, Madison Wl: 159-165. 